\section{Hyper-reactive malarial splenomegaly and splenic infarct in a caucasian toddler}

\author{
Anselm Chi-wai Lee \\ Children's Haematology and Cancer \\ Centre, Mount Elizabeth Hospital, \\ Singapore
}

\section{Abstract}

A 4-year-old boy from the United States had been staying in Indonesia for five months when he presented with fever, severe lethargy, progressive weight loss, and abdominal distension. He was first diagnosed with Plasmodium vivax infection in Indonesia and received treatment with chloroquine. However, his condition continued to deteriorate and he required erythrocyte transfusion for severe anemia. Three weeks into his illness, he was found to have low parasitemia with Plasmodium falciparum with massive hepatosplenomegaly in Singapore. A splenic infarct was also documented on computed tomography. Treatment with atovaquoneproguanil resulted in stabilization of the hemoglobin level and rapid reduction in splenic size, with clearance of malarial parasites from the bloodstream. Although reported typically in adult tropical residents, hyper-reactive malarial splenomegaly may occasionally be found in the pediatric traveler. Clinicians receiving children returning from the tropical regions should be aware of this potentially lifethreatening complication of partially treated malaria.

\section{Introduction}

The spleen plays an important role of clearing infected erythrocytes in malarial infection. ${ }^{1}$

Complications involving the spleen have been reported with infarction, ${ }^{2}$ abscess,${ }^{3}$ subcapsular hematoma, ${ }^{4}$ rupture, ${ }^{5}$ and hyper-reactive malarial splenomegaly (HMS) or tropical splenomegaly syndrome. ${ }^{6}$

The latter is commonly understood as an immunological reaction from the infected host and may be confused with lymphoproliferative syndromes. HMS is usually described in tropical residents as a result of chronic malarial infection, and is mostly recognized in young and middle-aged adults. ${ }^{6}$

A unique case of HMS complicated by splenic infarct affecting a Caucasian child is reported.

\section{Case Report}

A 4-year 11-month-old boy from the United States was staying with his family in a tribal region in Indonesia in the preceding five months. He had recurrent febrile illnesses during this period and had been given chloroquine intermittently as prophylaxis, but his general health started to deteriorate about a month before admission. The child complained of epigastric pains. He was noted to be febrile, increasingly tired, and losing weight. He was first admitted to a local hospital and was diagnosed to have Plasmodium vivax infection. He was treated with chloroquine (the exact treatment could not be verified) but the condition did not improve. He was also found to have increasing splenomegaly and severe anemia (lowest hemoglobin recorded, $3.6 \mathrm{~g} / \mathrm{dL}$ ). Red cell transfusion was carried out twice before he was evacuated to Singapore for further management.

The child's condition was stable on admission. Pallor was mild and there was no jaundice. The liver and spleen were grossly enlarged at $6 \mathrm{~cm}$ and $8 \mathrm{~cm}$ below the costal margins, respectively. The first full blood counts showed hemoglobin $9.8 \mathrm{~g} / \mathrm{dL}$, white cells $5.48 \times 10^{9} / \mathrm{L}$, platelet $123 \times 10^{9} / \mathrm{L}$. The red cells were anisopoikilocytic with prominent polychromasia and occasional nucleated forms. Immature trophozoites and gametocytes characteristic of Plasmodium falciparum were also seen (Figure 1), with a parasite load of $0.1 \%$. Treatment with atovaquone $500 \mathrm{mg}$ proguanil $200 \mathrm{mg}$ for three days was commenced.

Computed tomography revealed enlarged liver and spleen with no signs of thrombosis in the portal venous system. The liver parenchyma was normal. An area of infarction was found in the anterior aspect of the lower pole of the spleen (Figure 2).

Two days later, his hemoglobin dropped to $8.3 \mathrm{~g} / \mathrm{dL}$ and another red cell transfusion was given. Tests for glucose-6-phosphate dehydrogenase deficiency, direct Coombs test, and occult blood in stool were negative. Serum ferritin $(664 \mathrm{mg} / \mathrm{mL})$, bilirubin $(15 \mu \mathrm{mol} / \mathrm{L})$, aspartate transferase $(37 \mathrm{U} / \mathrm{L})$, and alanine transferase (14 U/L) were normal. Serologic tests for hepatitis $\mathrm{B}$, hepatitis $\mathrm{C}$, human immunodeficiency virus, and Parvovirus B19 were negative. Serum IgA $(0.81 \mathrm{~g} / \mathrm{L})$, and $\operatorname{IgG}$ $(10.4 \mathrm{~g} / \mathrm{L})$ were normal. Serum IgM was raised (2.97 g/L, normal 0.51-2.14). Lymphocyte subsets showed a mild increase in B cells $(663 / \mu \mathrm{L}$, normal 65-620) only.

A week after completion of the anti-malarial treatment, the child became more cheerful and had regained his premorbid body weight. The liver was no longer palpable and the spleen was $4 \mathrm{~cm}$ below the costal margin. Repeat
Correspondence: Anselm Lee, Children's Haematology and Cancer Centre, Level 4, Mount Elizabeth Hospital, 3 Mount Elizabeth, Singapore 228510 .

Tel. +65.673.126.73 - Fax: +65.623.549.24.

Email: anselm.cw.lee@gmail.com

Key words: hyper-reactive malarial splenomegaly, malaria,plasmodium falciparum, splenic infarction.

Conflict of interest: the authors report no conflicts of interest.

Received for publication: 12 October 2011. Revision received: 23 October 2011.

Accepted for publication: 30 0ctober 2011.

This work is licensed under a Creative Commons Attribution NonCommercial 3.0 License (CC BYNC 3.0).

CCopyright A.C. Lee, 2011

Licensee PAGEPress, Italy

Infectious Disease Reports 2011; 3:e13

doi:10.4081/idr.2011.e13

hemoglobin was $11.7 \mathrm{~g} / \mathrm{dL}$, identical to the post-transfusion measurement. Parasite load was less than $0.01 \%$, and no more parasites were seen on the blood film a week later.

\section{Discussion}

Hyper-reactive malarial splenomegaly is believed to be an immunological complication of malarial infection. ${ }^{7}$ Defective function of suppressive T cells leads to dysregulation of B cells and over-production of IgM. The deposition of immune complexes in the reticuloendothelial system results in the enlargement of the liver and spleen even in the absence of significant parasitemia as illustrated in this case. Clinico-

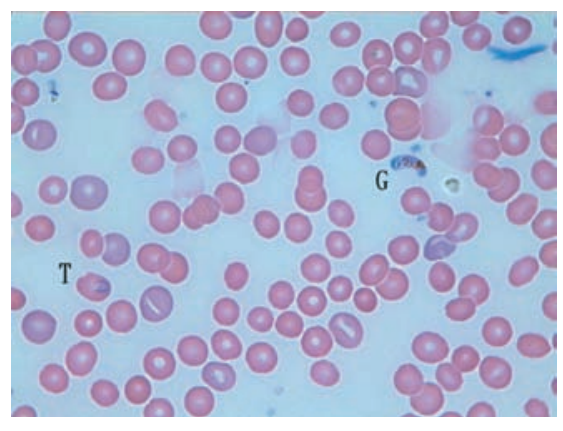

Figure 1. Photomicrograph of the peripheral blood film with Giemsa stain $(x 100)$ showing an immature trophozoite $(T)$ and a gametocyte (G) characteristic of Plasmodium falciparum infection. 
laboratory diagnostic criteria have been described. ${ }^{8}$ Differentiation from chronic lymphoproliferative disorders is important in the adult patient, but this is usually not an issue in childhood, though the condition has rarely been reported in pediatric ages. ${ }^{9,10}$ However, diagnostic confusion may happen as HMS may be mistaken as other febrile illnesses in the young child, ${ }^{9}$ or when the child presents late after

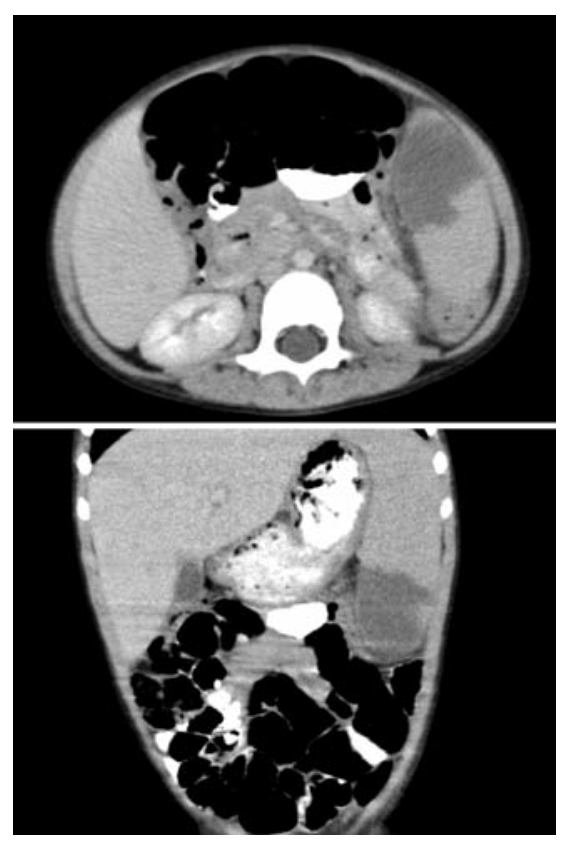

Figure 2. Axial and coronal contrastenhanced computed tomography showing an infarct in the anterior aspect of the lower pole in the enlarged spleen. returning from an endemic area. ${ }^{10}$

Splenic infarct is an unusual complication from malarial infection, but it is often innocuous and no treatment is required. ${ }^{2}$ Splenic infarct has to be distinguished from abscess which has also been noted after malarial infection. ${ }^{3}$ Spontaneous rupture is a recognized risk in patients with grossly enlarged spleens with an estimated risk of $2 \%$ in those affected by malaria. $^{5}$

Clinicians evaluating patients returning from the tropics should be aware that diagnostic and therapeutic details from remote healthcare facilities may be difficult to verify. Failure to eradicate the parasite may be encountered because of inaccurate parasite identification, re-infection, inadequate drug dosing, drug resistance, or omission of the treatment for the hepatic stage of infection. It is not clear if the malaria parasite had been misidentified or a co-infection with two malarial species had not been found at the initial stage in the reported case. Nevertheless, severe splenic complications following malaria should be looked out for in any child returning from the tropics, and they should be followed up for radical cure.

\section{References}

1. Chotivanich K, Udomsangpetch $\mathrm{R}$, McGready $R$, et al. Central role of the spleen in malaria parasite clearance. $\mathrm{J}$ Infect Dis 2002;185:1538-41.

2. Cinquetti G, Banal F, Rondel C, et al.
Splenic infarction during Plasmodium ovale acute malaria: first case reported. Malaria J 2010;9:288.

3. Contini S, Lewis HR. Spleen abscess as malaria complication. Emerg Infect Dis 2006;12:529-31.

4. Kumar GB, Shetty MA, Chakrapani. Splenic complications in malaria: a case series. Southeast Asian J Trop Med Public Health 2008;39:791-4.

5. Ozsoy MF, Oncul 0, Pekkafali F, et al. Splenic complications in malaria: report of two cases from Turkey. J Med Microbiol 2004;53:1255-8.

6. Allam MM, Alkadarou TA, Ahmed BG, et al. Hyper-reactivity malarial splenomegaly (HMS) in malaria endemic area in Eastern Sudan. Acta Trop 2008;105:196-9.

7. Piessens WF, Hoffman SL, Ahmed AW, et al. Antibody-mediated killing of suppressor T lymphocytes as a possible cause of macroglobulinemia in the tropical splenomegaly syndrome. J Clin Invest 1985;75:1821-7.

8. Bates I, Bedu-Addo G. Review of diagnostic criteria of hyper-reactive malarial splenomegaly. Lancet 1997; 349:1178.

9. Verma S, Aggrawal A. Hyper-reactive malarial splenomegaly: rare cause of pyrexia of unknown origin. Indian $\mathrm{J}$ Pediatr 2007; 4:409-11.

10. van den Ende J, van Gompel A, van den Enden E, Colebunders R. Development of hyperreactive malarious splenomegaly in an 8 year-old Caucasian boy, 18 months after residence in Africa. Ann Soc Belge Med Trop 1994;74:69-73. 